\title{
EKOGENOTOKSISITAS LIMBAH CAIR BATIK DAN EFEK ANTIMUTAGENIK Lemna minor TERHADAP ERITROSIT IKAN NILA (Oreochromis niloticus)
}

\author{
Ecogenotoxicity of batik liquid waste and antimutagenicity of Lemna minor \\ on Nile tilapia erithrocytes
}

\author{
Erma Musbita Tyastuti ${ }^{1)}$, Okid Parama A. ${ }^{2)}$, Sunarto $^{\text {() }}$ \\ Universitas Sebelas Maret, Jalan Ir. Sutami No. 36A Kentingan Surakarta, 57126 \\ E-mail korespondensi: ermatyastuti@gmail.com
}

\begin{abstract}
Batik liquid waste in Solo are mostly sent directly to water stream without any treatment. This activity may lead to water contamination. The liquid waste contains some heavy metals that induce genotoxicity such as micronucleus formation. Lemna minor has antimutagenic properties due to its active biological compounds (i.e. caroten and amino acids) and able to inhibit the formation of micronucleus. The objectives of this present study are to understand the ecogenotoxicity of batik liquid waste and antimutagenicity of Lemna minor on nile tilapia erithrocytes. This study were conducted in Biology Laboratory of UMS. Two groups of nile tilapia were fed with different diet, 1 group of Lemna minor and 1 group of comersial pelet then exposed to batik liquid waste on 0 $\mathrm{ppm} / \mathrm{L}, 2500 \mathrm{ppm} / \mathrm{L}, 5000 \mathrm{ppm} / \mathrm{L}$ and $7500 \mathrm{ppm} / \mathrm{L}$. The result showed that the exposure of batik liquid waste induced the formation of micronucleus in fish erithrocytes, the highest frequency of micronucleus formation was the exposure of $7500 \mathrm{ppm} / \mathrm{L}$. Lemna minor is proven to have the antimutagenicity and suppressed the formation of micronucleus lower than fish with pelet diet.
\end{abstract}

Keywords: batik liquid waste, ecogenotoxicity, micronucleus, Lemna minor, antimutagen.

Abstrak - Limbah cair batik di Solo sebagian besar dibuang langsung ke perairan tanpa diolah terlebih dahulu dan menyebabkan pencemaran air. Kandungan logam berat di dalam limbah cair batik dapat memicu efek genotoksik seperti pembentukan mikronukleus. Lemna minor berpotensi sebagai antimutagen dan mencegah pembentukan mikronukleus karena mengandung senyawa aktif seperti karoten dan asam amino. Penelitian ini bertujuan untuk mengetahui ekogenotoksisitas limbah cair batik dan efek antimutagenik Lemna minor terhadap eritrosit ikan nila. Penelitian dilakukan di Laboratorium Biologi UMS dengan pemaparan limbah cair batik 0ppm/L, 2500 ppm/L, 5000 ppm/L dan 7500 ppm/L terhadap 2 kelompok ikan nila dengan diet pelet dan Lemna minor. Hasil penelitian menunjukkan bahwa paparan limbah cair batik memicu pembentukan mikronukleus dengan frekwensi tertinggi pada konsentrasi paparan $7500 \mathrm{ppm} / \mathrm{L}$. Lemna minor juga terbukti memiliki potensi antimutagenik karena mampu menekan frekwensi mikronukleus lebih rendah dibandingkan diet pelet.

Kata kunci: limbah cair batik, ekogenotoksisitas, mikornukleus, Lemna minor, antimutagen.

\section{PENDAHULUAN}

Ekogenotoksikologi adalah suatu bentukpendekatanyangmengaplikasikan prinsip dan tehnik genetika toksikologi untuk menilai efek potensial dari polusi lingkungan dalam bentuk agen genotoksik terhadap kesehatan ekosistem (Akpoilih, 2012; Shugart and Theodoralis, 1998).
Limbah cair batik mengandung logam berbahaya yang dapat mengganggu kesehatan, diantaranya adalah $\mathrm{Cr}, \mathrm{Cu}$, $\mathrm{Cd}, \mathrm{Fe}, \mathrm{Mn}$ dan $\mathrm{NH}_{3} \mathrm{~N}$ (Aryani dkk., 2004; Hartanti dkk., 2011; Putra dkk., 2014; Sasongko dan Tresna, 2010; Subki dkk., 2014). Beberapa studi ekogenotoksikologi terhadapa organisme perairan telah mebuktikan bahwa paparan logam 
berat mampu memicu kerusakan DNA, pembentukan mikronukleus, kelainan kromosom, mutasi sel, perkembangan sel kanker dan kerusakanjanin serta beberapa gangguan kesehatan lainnya (Cadalwa et al., 2008; Martin and Griswold, 2009; Mohod and Dhote, 2013).

Mikronukleus didefinisikan sebagai badan ekstra-nuklear yang mengandung fragmen kromosom dan atau keseluruhan kromosom yang tidak bergabung dengan nukleus setelah proses pembelahan sel (Luzhna et al., 2013). Mikronukleus dapat dengan mudah dibedakan dari nukleus utama sel karena memiliki karakteristik sebagai berikut : (i) badan ekstra nuklear di dalam sitoplasma, berbentuk bulat atau lonjong, (ii) diameter 1/3 - 1/20 dari nukleus utama di dalam sel, (iii) tekstur, warna dan penampakan menggambarkan nukleus utama, (iv) posisi benar-benar terpisah dari nukleus utama. (Ayoola and Akaeze, 2012).

Antimutagen dideskripsikan sebagai agen yang dapat mengurangi akibat yang muncul karena mutasi spontan maupun sengaja dipicu. Mekanisme anti mutagenesis diklasifikasikan menjadi 2 proses utama, yaitu :

a. Desmutagenesis : faktor yang berperan langsung pada mutagen atau menginaktifasi mutagen. Zat yang berperan disebut desmutagen

b. Bio anti mutagenesis : faktor yang berperan pada proses mutagenesis atau memperbaiki kerusakan DNA sehingga menurunkan frekwensi mutasi yang terjadi (Nagarathna et al., 2013).

Beberapa kelompok utama senyawa antimutagenik diantaranya adalah vitamin, flavonoid, senyawa fenol, antrakuinon, karotenoid, diterpenoid, kumarin, tanin, hormon steroid, saponin dan produk-produk dari laut
(Bhattacharya, 2011; Sloczynska et al., 2014), serta beberapa kelompok asam amino (Mauro et al., 2009; Srividya et al., 2012).

Lemna minor adalah tumbuhan kecil yang hidup mengambang di perairan, tersebar luas di seluruh penjuru dunia dan sering ditemui tumbuh sebagai populasi yang membentuk selimut tebal di permukaan air yang kaya akan nutrisi. Lemna minor adalah tumbuhan monokotil yang termasuk ke dalam famili Lemnaceae dan diklasifikasikan sebagai makrofit. Berdasarkan beberapa penelitian, diketahui bahwa Lemna minor memiliki banyak manfaat diantaranya sebagai agen biomonitoring dan bioremediator pencemaran air (Azeez and Sabbar, 2012; Khellaf and Zerdaoun, 2010; Paczkowski et al., 2007; Radic et al., 2009), bahan pakan alami bagi ikan (Olaniyi and Oladunjoye, 2012; Yilmaz et al., 2004); bebek (Ali dkk., 2014); ayam (Hanstein et al., 1992), antioksidan, antibakteri dan antifungal (Gulcin et al., 2010)

Ikan nila dianggap sebagai bioindikator yang sangat bagus untuk studi genotoksikologi perairan dan untuk monitoring lingkungan karena mudah didapat, mudah beradaptasi di segala kondisi lingkungan dan memiliki nilai komersial yang tinggi (Bucker and Conceicao, 2012). Secara umum ikan adalah organisme yang paling sensitif terhadap efek genotoksik yang disebabkan oleh polutan karena beberapa alasan berikut ini : bioindikator yang sensitif terhadap kualitas air dan menunjukkan bahaya dari bahan-bahan kimia yang masuk ke dalam perairan; merespon toksikan seperti respon vertebrata yang lebih tinggi tingkat taksonnya; memiliki kemampuan yang lebih besar untuk memetabolisme xenobiotik dan mengakumulasi polutan; mampu hidup di segala zona perairan dan memiliki nilai 
komersial serta rekreasional yang tinggi; memiliki peran penting dalam jaring tropik seperti mengalami bioakumulasi polutan dan biotransformasi xenobiotik seperti mamalia; merespon mutagen dalam konsentrasi rendah; sel tubuh ikan memiliki mekanisme perbaikan yang rendah; jika dibandingkan dengan sel mamalia, sel ikan lebih sensitif terhadap induksi kerusakan DNA; perbaikan DNA yang rusak lebih lambat dibandingkan mamalia sehingga cocok untuk studi biomonitoring (Mir et al., 2014).

\section{METODE PENELITIAN}

Penelitian dilakukan padabulanAprilMei 2016, bertempat di Laboratorium Biologi FKIP UMS Surakarta. Penelitian ini merupakan penelitian eksperimental laboratoris dengan menggunakan 8 perlakuan dengan 5 kali ulangan. Limbah cair batik didapatkan dari bak tampungan IPAL industri batik di wilayah Kampung Batik Laweyan, Solo. Lemna minor didapatkan dari penggiat Lemna minor di desa Banyudono, Boyolali kemudian dikembangbiakkan di bak pembiakan. Sedangkan ikan nila sehat dengan berat 30-50 gram dan panjang 8-10 cm didapatkan dari Balai Benih Ikan Dinas Peternakan Surakarta.

\section{Pemberian pakan}

Hewan uji dibagi menjadi 2 kelompok pakan yaitu kelompok pelet (P) dan kelompok Lemna (L). Pemberian pakan dilakukan $2 \times$ setiap hari pada pagi hari dan sore hari. Sisa pakan dibersihkan setiap 24 jam sekali untuk menjaga kondisi air di aquarium. Air yang digunakan harus dalam kondisi : $\mathrm{pH}$ 6.9 \pm 0.3 ; DO $4.8 \pm 0.2 \mathrm{mg} / \mathrm{L}$; suhu $23.59 \pm 0.24^{\circ} \mathrm{C}$. Pemeliharaan ikan dengan fotoperiode 12-14 jam selama
7 hari. Pemberian pakan dihentikan satu hari sebelum pemaparan limbah cair batik.

\section{Paparan limbah cair batik}

Sebelumnya dilakukan uji pendahuluan untuk menentukan LC50-96 dan didapatkan LC50-96 sebesar $13.601 \mathrm{ppm} / \mathrm{L}$. Berdasarkan hasil di atas maka ditetapkan konsentrasi untuk uji sebenarnya sebagai berikut :

a. Kelompok perlakuan A dengan penambahan limbah $0 \mathrm{ppm} / \mathrm{L}$ air sebagai kontrol.

b. Kelompok perlakuan B dengan penambahan limbah 2500 ppm/L air.

c. Kelompok perlakuan C dengan penambahan limbah 5000 ppm/L air.

d. Kelompok perlakuan D dengan penambahan limbah 7500 ppm/L air.

\section{Penghitungan jumlah mikronukleus}

Setelah 96 jam paparan limbah cair batik, ikan nila dibius untuk proses pengambilan darah. Darah diambil dari vena cauda dengan menggunakan syringe yang telah dilengkapi EDTA agar darah tidak cepat membeku. Darah yang telah diambil segera dibuat preparat apus darah di atas gelas obyek kemudian dikeringanginkan pada suhu ruang semalaman. Apusan darah difiksasi dengan methanol absolut selama 10 menit dan dilanjutkan dengan pewarnaanmenggunakan Giemsa $10 \%$ selama 1 jam. Untuk tiap sampel darah dari satu individu ikan dibuat 2 preparat apus darah untuk pengamatan 1000 eritrosit, penghitungan 500 eritrosit untuk tiap preparat dan diamati ada tidaknya 
mikronuleus dan nukleus abnormal lainnya. Pengamatan eritrosit menggunakan mikroskop cahaya dengan perbesaran 1000x (Kousar and Javed, 2015; Srivastava and Singh, 2015 dengan beberapa modifikasi). Untuk mempermudah proses penghitungan eritrosit, mikroskop dilengkapi dengan optilab yang berfungsi mengambil gambar eritrosit yang teramati. Mikronukleus yang telah teramati kemudian dihitung frekuensinya dengan menggunakan rumus sebagai berikut :

$$
\operatorname{FMN~}(\%)=\frac{\begin{array}{c}
\text { Jumlah mikronukleus } \\
\text { yang teramati }
\end{array}}{\begin{array}{c}
\text { Jumlah total sel yang } \\
\text { diamati }
\end{array}} \times 100
$$

(Kousar and Javed, 2015)

\section{Analisis dan Interpretasi Data}

Data frekwensi mikronukleus dianalisis secara non parametrik menggunanakan uji Kruskal-Wallis untuk memperbandingkan antara kelompok paparan limbah dan jenis pakan $(\mathrm{p}<0.05)$.

\section{HASIL DAN PEMBAHASAN}

\section{Ekogenotoksisitas limbah cair batik terhadap pembentukan mikronukleus eritrosit ikan nila.}

Hasil penelitian menunjukkan bahwa paparan limbah cair batik telah memicu pembentukan mikronukleus pada beberapa konsentrasi uji. Hasil dapat dilihat pada table 1. Data pada tabel menunjukkan bahwa paparan limbah cair batik telah memicu pembentukan mikronukleus pada beberapa konsentrasi paparan dan frekwensi mikronukleus cenderung meningkat seiring dengan peningkatan konsentrasi paparan.
Tabel 1. Frekwensi mikronukleus pada eritrosit ikan nila dengan beberapa konsentrasi paparan limbah cair batik

\begin{tabular}{ll}
$\begin{array}{c}\text { Konsentrasi } \\
\text { paparan } \\
\text { limbah cair batik }\end{array}$ & $\begin{array}{c}\text { \% Frekwensi } \\
\text { mikronukleus } \\
\text { eritrosit } \\
\text { (Mean } \pm \text { SD) }\end{array}$ \\
\hline $0 \mathrm{ppm} / \mathrm{L}$ (kontrol) & 0 \\
\hline $2500 \mathrm{ppm} / \mathrm{L}$ & $1.40 \pm 1.647$ \\
$5000 \mathrm{ppm} / \mathrm{L}$ & $1.00 \pm 1.155$ \\
$7500 \mathrm{ppm} / \mathrm{L}$ & $2.10 \pm 1.792$ \\
\hline
\end{tabular}

Frekwensi tertinggi terdapat pada konsentrasi paparan 7500 ppm/L dan memiliki perbedaan yang signifikan dengan konsentrasi yang lebih rendah. Sedangkan pada kontrol tidak terdeteksi adanya mikronukleus pada eritrosit ikan nila. Semakin tinggi konsentrasi limbah cair batik maka semakin tinggi juga kadar pencemar yang terkandung di dalamnya, sehingga memicu semakin tingginya frekwensi pembentukan mikronukleus. Mikronukleus yang terbentuk pada eritrosit ikan nila dapat dilihat pada gambar 1 .

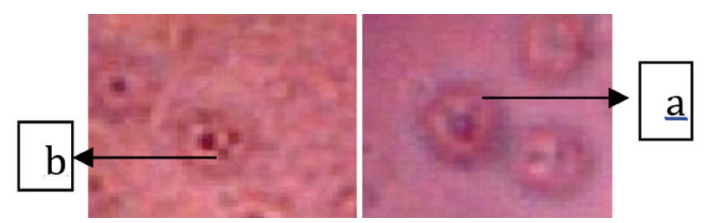

Gambar 1. Mikronukleus yang terbentuk di eritrosit ikan nila (a) dan (b). Mikronukleus yang diamati berukuran 1/3-1/40 dari nukleus utama.

Pembentukan mikronukleus pada uji ini diperkirakan karena paparan logam berat yang terkandung pada limbah cair batik. Beberapa studi telah mengindikasikan bahwa logam berat dapat menimbulkan efek genotoksik salah satunya adalah pembentukan mikronukleus. Logam berat dapat berperan baik secara tunggal maupun 
bersama-sama (polimetal). Pada limbah cair batik yang digunakan dalam studi ini terkandung logam $\mathrm{Cr}$, $\mathrm{Cd}, \mathrm{Mn}, \mathrm{Fe}$ dan $\mathrm{Cu}$. Masing-masing jenis logam tersebut memiliki potensi genotoksik yang spesifik terhadap sel-sel tubuh organisme.

Cr terdapat di lingkungan dalam tiga tahapan oksidasi yang stabil yaitu $\mathrm{Cr}$ (0), $\mathrm{Cr}$ (III) dan $\mathrm{Cr}$ (VI) dimana masing-masing memiliki karakteristik toksisitas dan transport yang berbeda. Cr (VI) atau hexavalen adalah bentuk yang paling beracun bagi manusia maupun hewan karena potensi oksidasinya tinggi dan mampu menembus membran sel. Selain terindikasi toksik, Cr (VI) juga merupakan agen karsinogenik dan dapat menghancurkan struktur DNA. (Govind and Madhuri, 2014; Lin et al., 2009; Shadreck and Mugazda, 2013).

Penelitian oleh Kumar et al. (2012) terhadap ikan Channa punctatus menunjukkan bahwa paparan konsentrasi subletal potasium kromat selama 21 hari menginduksi pembentukan MN secara maksimal pada eritrosit, sedangkan paparan selama 7 hari memicu pembentukan ekor komet pada limfosit dan sel insang secara maksimal dengan uji commet assay. Pada penelitian lain dilakukan pemaparan $\mathrm{Cr}$ selama 21 hari pada ikan Catla catla dan hasil yang didapatkan menunjukkan adanya peningkatan frekwensi MN dan nukleus binuklear secara signifikan pada eritrosit ikan yang dipicu oleh peningkatan kerusakan DNA dan seiring dengan penurunan aktifitas enzim SOD serta peningkatan aktifitas enzim katalase (Arunachalan etal., 2013). Penelitian Rasal etal.(2011) juga memperkuat bukti tentang efek genotoksik Cr. Penelitian dilakukan terhadap ikan Labeo rohita dengan paparan potasium dikromat, bentuk terlarut dari hekasavalen $\mathrm{Cr}$ (VI). Hasil menunjukkan bahwa terjadi pembentukan MN pada eritrosit ikan setelah paparan potasium dikromat baik pada konsentrasi subletal maupun nonletal.

$\mathrm{Cd}$ adalah logam non essensial yang banyak dilepas di lingkungan sebagai limbah industri dan merupakan logam yang dapat mengendap di dalam jaringan tubuh dalam waktu yang lama (10-30 tahun) dan lambat proses ekskresinya (Ercal et al., 2001). Dubey dan Tripathi (2014) melakukan pengamatan efek genotoksisitas paparan $\mathrm{Cd}$ terhadap 3 jenis jaringan pada ikan Channa punctatus yaitu eritrosit, sel-sel ginjal dan sel-sel insang selama 96 jam dengan uji MN. Hasilyang didapatkan menunjukkan bahwa frekwensi MN tertinggi terdapat pada sel insang, kemudain eritrosit dan terakhir pada sel ginjal. Semakin lama paparan dan semakin tinggi konsentrasi paparan $\mathrm{Cd}$ maka semakin tinggi juga frekwensi MN. Hasil yang sama juga didapatkan oleh Ozkan et al. (2011) yang melakukan studi efek genotoksik Cd pada ikan Oreochromis niloticus, bahwa semakin tinggi dosis $\mathrm{Cd}$ dan semakin panjang durasi paparan meningkatkan frekwensi pembentukan MN.

$\mathrm{Mn}, \mathrm{Fe}$ dan $\mathrm{Cu}$ adalah logam essensial yang dalam batasan tertentu berguna dalam metabolime namun jika dalam jumlah yang berlebih dapat menjadi racun bagi tubuh (Flora et al., 2008). Ketiga logam tersebut dapat memicu kerusakan DNA secara oksidatif dengan membentuk radikal bebas. Radikal bebas berupa Fe bebas, $\mathrm{Mn}$ bebas, $\mathrm{Cu}$ bebas, $\mathrm{OH}^{-*}$ 
atau $\mathrm{O}^{2-*}$. Pembentukan radikal hidroksil melalui jalur reaksi Fenton dan Haber-Weiss. Radikal bebas yang mengoksidasi DNA menyebabkan terjadinya substitusi basa pada DNA dan memicu mutasi. Selain berperan langsung terhadap DNA, radikal bebas juga memicu kerusakan enzimenzim antioksidan dan enzim-enzim perbaikan DNA sehingga kerusakan pada DNA lambat diperbaiki atau bahkan tidak dapat diperbaiki. Kondisi inilah yang bisa memicu pembentukan MN (Anderson et al., 2007; Dziaman et al., 2011; Jaishankar et al., 2014; Okocha and Adedeji, 2012; Papanikolaou and Pantopoulos, 2005; Stephenson et al, 2013; Toyokuni, 2009). Penelitian oleh Horta et al. (2016) membuktikan bahwa logam Fe dapat memicu pembentukan MN secara in vivo pada limfosit mencit. Logam $\mathrm{Cu}$ juga telah terindikasi dapat menginduksi pembentukan mikronukleus pada larva katak Lithobates catabieanus (Da Rocha, 2011) dan pada beberapa spesies ikan yaitu Labio rohita, Cirrhina mrigala, Ctanopharygodon idella dan Catla catla setelah 30 hari paparan (Kousar and Javeed, 2015).

\section{Efek antimutagenik Lemna} minor terhadap pembentukan mikronukleus eritrosit ikan nila setelah pemaparan limbah cair batik.

Pemaparan limbah cair batik dilakukan setelah sebelumnya 2 kelompok ikan nila diberi 2 jenis pakan yang berbeda. Kelompok 1 diberi pakan pelet sebagai kontrol sedangkan kelompok 2 diberi pakan Lemna minor sebagai kelompok perlakuan. Hasil pengamatan pembentukan mikronukleus setelah paparan dapat dilihat pada tabel 2 .
Tabel 2. Frekwesi mikronukleus di tiap konsentrasi paparan limbah cair batik pada 2 jenis pakan yang berbeda (pelet dan Lemna minor)

\begin{tabular}{|ccc|}
\multirow{2}{*}{$\begin{array}{c}\text { Konsentrasi } \\
\text { paparan limbah } \\
\text { cair batik }\end{array}$} & \multicolumn{2}{c|}{$\begin{array}{c}\text { Frekwensi mikronukleus } \\
\text { (Mean } \pm \text { SD) }\end{array}$} \\
\cline { 2 - 3 } 0 & Pelet & $\begin{array}{c}\text { Lemna } \\
\text { minor }\end{array}$ \\
$0 \mathrm{ppm} / \mathrm{L}($ kontrol) & 0 & 0 \\
\hline $2500 \mathrm{ppm} / \mathrm{L}$ & $2.20 \pm 2.049$ & $0.60 \pm 0.548$ \\
$5000 \mathrm{ppm} / \mathrm{L}$ & $1.40 \pm 1.517$ & $0.60 \pm 0.548$ \\
$7500 \mathrm{ppm} / \mathrm{L}$ & $3.60 \pm 1.140$ & $0.60 \pm 0.548$ \\
\hline
\end{tabular}

Dalam studi ini belum dapat ditentukan peran spesifik Lemna minor, apakah sebagai desmutagen atau bioantimutagen. Diperlukan studi lanjutan untuk mengetahui mekanisme kerja Lemna minor dalam menghambat pembentukan mikronukleus sehingga peran spesifik antimutagennya dapat diketahui.

Untuk memperkirakan mekanisme kerja antimutagen Lemna minor, bisa dilihat dari kandungan kimiawi yang dimiliki. Lemna minor kaya akan protein dan asam amino yang memiliki efek antimutagenik. Roy et al. (2002) telah menguji aktifitas antimutagenik dari 19 asam amino (kecuali histidin) terhadap daya mutagenik $\mathrm{N}$-metil-N'-nitroNnitroguanidin (MNNG) dengan uji AMES dan didapatkan hasil bahwa sistein adalah antimutagen teraktif dan glisin, triptofan, lisin dan arginin sebagai antimutagen kuat, sedangkan sisanya menunjukkan aktifitas antimutagenik menengah hingga lemah. Asam amino juga berperan sebagai chelator, yaitu senyawa yang mampu mengikat logam berat dan mencegah toksisitas logam berat (Marara, 2012). Pengikatan logam berat oleh chelator mencegah pembentukan ROS dan mutasi pada 
sel. Lemna minor juga mengandung karoten yang merupakan prekursor vitamin A, memiliki daya antioksidanyang berperan sebagai antimutagen dan menginaktifasi mutagen sehingga Lemna minor bisa berperan sebagai antimutagen dengan potensi antioksidan (Flora et al., 2008). Antioksidan mampu menghilangkan ROS sebelum molekul mutagen bereaksi dengan DNA dan menyebabkan mutasi (Sloczynska et al., 2014). Lemnan, senyawa pektin kompleks juga ditemukan terkandung di dalam Lemna minor (Gulcin, 2010). Pektin adalah kelompok polisakarida yang ditemukan di dinding sel tumbuhan tingkat tinggi dengan fungsi sebagai agen penghidrasi dan bahan pemadat untuk jaringan selulosa (Thakur et al., 1997). Pektin juga berperan sebagai chelator bagi logam berat sehingga mencegah mutasi sel karena pembentukan ROS. Zhao et al. (2008) menguji peran pektin pada jeruk sebagai chelator pada detoksifikasi timbal terhadap anak-anak yang dirawat di rumah sakit karena keracunan timbal. Hasil uji menunjukkan penurunan kadar timbal pada serum darah dan peningkatan kadar timbal pada urin anak-anak tersebut.

Semakin beragamnya bahanbahan mutagenik yang terlepas di lingkungan maka semakin tinggi juga ancaman genotoksik yang dapat menurunkan kualitas hidup makhluk hidup. Efek genotoksik adalah pemicu awal berkembangnya gangguan-gangguan sistem fisiologis pada makhluk hidup. Potensi antimutagenik yang dimiliki oleh Lemna minor menjadikan tumbuhan ini sebagai salah satu alternatif solusi dalam mencegah atau meminimalisir efek genotoksik bahan-bahan mutagenik.

\section{SIMPULAN, SARAN, DAN REKOMENDASI}

Limbah cair batik memiliki efek ekogenotoksik terhadap eritrosit ikan nila karena mampu memicu pembentukan mikronukleus. Kandungan logam berat di dalam limbah cair batik sebagai salah satu pemicu munculnya efek genotoksik pada eritrosit ikan nila. Logam berat yang terkandung di dalam limbah cair batik adalah Cd, Cr, Fe, Mn dan Cu. Lemna minor berpotensi sebagai antimutagenik karena mampu meminimalisir pembentukan mikronukleus pada eritrosit ikan nila. Belum dapat ditentukan aktifitas antimutagenik yang utama pada Lemna minor, apakah sebagai desmutagen atau bioantimutagen.

\section{DAFTAR PUSTAKA}

Akpoilih, B. U. 2012. "Fish Ecogenotoxicology: An Emerging Scinece, An Emerging Tool for Environmental Monitoring and Risk Assessment". G.J.B.B. 1 (2) : 141-151. ISSN : 2278-9103

Ali, M., Sukirno, Tamzil, M. H. and Ichsan, M. 2014. "Meat Traits of Msucovy Ducks Fed on Phytonutrition Meal". Int. J. Poult. Sci. 13 (4) : 204207. ISSN : 1682-8356

Anderson, G. 2007. "Mechanism of Iron Loading and Toxicity". Am. J. Hematol. 82 : 1128-1131. DOI : 10.1002/ajh.21075

Arunachalan, K.D., Annamalai, S.K. and Kuruva, J. K. 2013. "In Vivo Evaluation of Hexavalent Chromium Induced DNA Damage by Alkaline Comet Assay and Oxidative Stress in Catla catla". AJES 9 (6) : 470-482. DOI : 10.3844/ajessp.2013.470.482 
Aryani, Y., Sunarto dan Widiyani, T. 2004. "Toksisitas Akut Limbah Cair BatikCV.GiyantSantosoSurakarta dan Efek Sublethalnya Terhadap Struktur Mikroanatomi Branchia dan Hepar Ikan nila (Oreochromis niloticus)". BioSMART. 6 (2) : 147153. ISSN : 1412-033x

Ayoola, S. O. and Akaeze, c. O. 2012. "Genotoxic Evaluation and Toxicity of Spent Engine Oil on Clarias gariepinus". Res. J. Environ. Toxicol. 6 (4) : 133-141. ISSN : 1819-3420. DOI : 10.3923/ rjet.2012.133.141.

Azeez, N. M. and Sabbar, A. A. 2012. "Efficiency of Duckweed (Lemna minor L.) in Phytotreatment of Wastewater Pollutants from Basrah Oil Refinery". J. Appl. Phytotech. Environ. Sanit. 1 (4) : 163-172. ISSN : 2088-6586

Bhattacharya, Sanjib. 2011. "Natural Antimutagens : A Review". Res. J. Med. Plant. 5 (2) : 116-126. ISSN : 1819-3455. DOI : 10.3923/ rjmp.2011.116.126

Bucker, A. and da Conceicao, M. B. 2012. "Genotoxicity evaluation of tilapia (Oreochromis niloticus) exposed to waters from two sites of Itajai-Acu River (SC, Brazil)". J. Braz. Soc. Ecotoxicol. 7 (2) : 51-56. DOI : 10.5132/jbse.2012.02.008

Cadahia, B. P., Laffon, B., Porta, M., Lafuente, A., Cabaleiro, T., Lopez, T., Caride, A., Pumarega, J., Romero, A., Pasaro, E. and Mendez, J. 2008. "Relationship Between Blood Concentration and Endocrine Parameters Among Subjects Involved in Cleaning Coastal Areas Affected by The 'Prestige' Tanker Oil Spill". Chemosphere. 71 : 447-455. DOI :10.1016/j. chemosphere.2007.10.053
Da Rocha, C. A. M. 2011. "The micronucleus Test in Erythrocytes of Amphibian Larvae as Tool for Xenobiotic Exposure Risk Assessment : A Brief Review and An Example Using Lithobates catesbieanus Exposed to Copper Sulphate". Middle-East. J. Sci. Res. 8 (1) : 23-29. ISSN : 1990-9233

Dubey, A. and Tripathi, N.K. 2014. "Evaluation of Time, Dose, and Tissue Dependent Genotoxic Effect of Cadmium Chloride in a Freshwater Fish, Channa punctatus (Pisces : Family : Channidae)". IJRSR 5 (5) : 934-939. ISSN : 09763031

Dziaman, T., Jurgowiak, M. and Olinski, R. 2011. "Association between body iron stores and level of oxidatively modified DNA bases". JBCBB 92 (2) : 159-165

Flora, S. J. S., Mittal, M. and Mehta, A. 2008. "Heavy metal induced oxidative stress and its possible reversal by chelation therapy". Indian. J. Med. Res. 128 : 501-523

Gulcin, I., Kurecci, E., Akkenik, E., Topal, F. and Hisar, O. 2010. "Antioxidant, Antibacterial and Anticandidal Activities of Aquatic Plant : Duckweed (Lemna minor L. Lemnaceae). Turk. J. Biol. 34 : 175188

Hartati, I., Riwayati, I. dan Kurniasari, L. 2011. "Potensi Xanthate Pulpa Kopi Sebagai Adsorben Pada Pemisahan Ion Timbal dari Limbah Industri Batik". Momentum. 7 (2) : 25-30

Horta, R.N., Kahl, V. F. S., Sarmento, M. S., Nunes, M. F. S., Porto, C. R. M., de Andrade, V. M., Ferraz, A. B. F. and Da Silva, J. 2016. "Protective effects of acerola juice 
on genotoxicity induced by iron in vivo". GMB 39 (1) : 122-128. DOI : $10.1590 / 1678-4685-G M B-$ 2015-0517

Jaishankar, M., Tseten, T., Anbalagan, N., Mathew, B. B. and Beeregowda, K. 2014. "Toxicity, mechanism and health effects of some heavy metals". Interdiscip. Toxicol. 7 (2) : 60-72. DOI : 10.2478/ intox-2014-0009

Khellaf, N. and Zerdaoui, M. 2010. "Growth, Photosynthesis and respiratory Response to Copper in Lemna minor : A Potential Use of Duckweed in Biomonitoring". Iran. J. Environ. Health. Sci. Eng. 7 (2) : 299-306

Kousar, S and Javed, M. 2015. "Studies on Induction of Nuclear Abnormalities in Peripheral Blood Erythrocytes of Fish Exposed to Copper". Turk. J. Fish. Aquat. Sci. $15: 879-886$. ISSN : 1303-2712. DOI : 10.4194/1303-2712-V15_4_11

Kumar, R., Nagpure, N.S., Kushwaha, B., Srivastava, S. K. and Lakra, W. S. 2010. "Investigation of the genotoxicity of malathion to freshwater teleost fish Channa punctatus (Bloch) using the micronucleus test and commet assay". Arch. Environm. Contam. Toxicol. 58 : 123-130. DOI : 10.1007/ s00244-009-9354-3

Lin, C. C., Wu, M. L., Yang, C. C., Ger, J., Tsai, W. J. and Deng, J. F. 2009. "Acute Severe Chromium Poisoning After Dermal Exposure to Hexavalent Chromium". J. Chin. Med. Assoc. 72 (4) : 219-221. DOI : 10.1016/s1726-4901 (09) 70059-0

Luzhna, L., Kathiria, B. and Kovalchuk, O. 2012. "Micronuclei in Genotoxicity Assessment : From Genetics to Epigenetics and Beyond". Frontiers in Genetics. 4 Article 131. DOI : 10.3389/fgene.2013.00131

Marara, A. 2012. "Plant Response to Heavy Metal Toxicity" in A. Furim (ed). Plants and Heavy Metals. Springerbriefs in BioMetals. DOI : 10.1007/978-94-007-4441-7_2

Martin, S.and Griswold, W. 2009. “Human Health Effects of Heavy Metals". Environmental Science and Technology Briefs for Citizens. 15th Ed. CHSR. KSU. Manhattan. New York

Mauro, M. O., Pesarini, J. R., Ishii, P. L., daSilva, A. F. and Oliveira, R. J. 2010. "Chemopreventive Activity of Phenylalanine Againts Damage Mutagenic Prompted by the Acute Administration of Cyclophosphamide in Pregnant and Non-Pregnant Mice Using the Micronucleus Test". Braz. J. Pharmacogn. 20 (3) : 334-339

Mir, M. I., Khan, S., Bhat, S. A., Reshi, A. A., Shah, F. A., Balki, M. H. and Manzoor, R.2014. "Scenario of Genotoxicity in Fishes and Its Impact on Fish Industry". IOSRJESTFT. 8 (6) : 2319-2402. E-ISSN : 2319-2402

Mohod, C. V. and Dhote, J. 2013. "Review of Heavy Metals in Dringking Water and Their Effect on Human Health". IJIRSET. 2 (7) : 2992-2996

Nagarathna, P. K. M., wesley, M. J., Reddy, P. S. and Renna, K. 2013. "Review on Genotoxicity, Its Molecular Mechanism and Prevention". Int. J. Pharm. Sci. Rev. Res. 22 (1) : 236243. ISSN : 0976-044x

Okocha, R. O. and Adedeji, O. B. 2012. "Overview of Copper Toxicity to Aquatic Life". Rep. Opinion. 4 (8) : 57-67. ISSN : 1553-9873 
Olaniyi, C. O. and Oladunjaye, I. O. 2012. "Replacement Value of duckweed (Lemna minor) in Nile tilapia (Oreochromis niloticus) Diet". Transnat.J. Sci. Tech. 2 (9) : 54-61

Ozkan, F., Gunduz, S. G., Berkoz, M. and Ozlner Hunt, A. 2011. "Induction of micronuclei and other nuclear abnormalities in peripheral erythrocytes of Nile tilapia, Oreochromis niloticus, following exposure to sublethal cadmium dose". Turk. J. Zool. 35 (4) : 585592. DOI : 10.3906/zoo-0907-77

Paczkowska, M., Kozlowska, M. and Golinski, P. 2007. "Oxidative Stress Enzyme Activity in Lemna minor L. Exposed to Cadmium and Lead". ACTA BIOLOGICA CRACOVIENSIA Series Botanica. 49 (2) : 33-37. PL ISSN : 0001-5296

Papanikolaou, G. and Pantopoulos, K. 2005. "Iron metabolism and toxicity". Toxicol. Appl. Pharmacol. 202 : 199-211. DOI : 10.1016/ jtaap.2004.06.021

Putra, D. E., Astuti, F. P. dan Suharyadi, E. 2014. "Studi Penurunan Kadar Logam Besi (Fe) pada Limbah Batik dengan Sistem Purifikasi Menggunakan Absorben Nanoparrtikel Magnetic (Fe3O4)". Prosiding Pertemuan Ilmiah XXVIII HFI Jateng dan DIY : 250-252. ISSN : 0853-0823

Radic, S., Stipanicev, D., Cvjetko, P., Mikelic, I. L., Rajcic, M. M., Sirac, S., Kozlina, B. P. and Pavlica, M. 2009. "Ecotoxicological Assessment of Industrial Effluent Using Duckweed (Lemna minor L.). as A Test Organism". Ecotoxicology. DOI 10.1007/s10646009-0408-0
Rasal, K., Rasal, A. and Makwana, N. 2011. "Micronucleus test as a cytogenetic marker for evaluation of genotoxicity in fish, Labeo rohita". Asian J. Animal. Sci. 6 (1) : 32-34

Roy, M. K., Kuwabara, Y., Hara, K., Watanabe, Y. and Tamai, Y. 2002. "Antimutagenic Effects of Amino Acids on the Mutagenicity of N-methyl-N-nitro-Nnitrosoguadinine (MNNG)". Biosc. Biotechnol. Biochem. 66 (6) : 14001402. DOI : $10.1271 / 666.66 .1400$

Sasongko, DwiP.2010.“IdentifikasiUnsur dan Kadar Logam Berat pada Limbah Pewarna Batik dengan Metode Analisis Pengaktifan Neutron". TELAAH. $27: 22-27$

Shadreck, M. and Mugadza, T. 2013. "Chromium, an essential nutrient and pollutant: A Review". AJPAC 7 (9) : 310-317. DOI : 10.5897/ AJPAC 2013.0517

Shugart, L. and Theodorakis, C. 1998. "New Trends in Biological Monitoring : Application of Biomarkers to Genetic Ecotoxicology". Biotherapy. 11 : 119-127

Sloczynska, K., Powraznik, B., Pekala, E. and Waszkielewicz. 2014. "Antimutagenic Compounds and Their Possible Mechanism of Action". J. Appl. Genetics. 55 : 273285. DOI : 10.1007/513355-0140198-9

Srivastava, P. and Singh, A. 2015. "Evidence of Micronuclei in Fish Blood as A Biomarker of Genotoxicity due to Surface Run of Agricultural Fungicide (Propiconazole)". J Toxicol. Environ. Health. Sci. 7 (1) : 4-8. 
Article Number : 845D77C50247. ISSN : 2006-9820. DOI : 10.5897/ JTEHS2015.0325

Srividya, A. R., Dhanabal, S. P. and Vishnuvarthan, V. J. 2012. "Mutagenicity/Antimutagenicity of Plant Extracts Used in Traditional Medicine : A Review". WJPR. 2 (1) : 236-259. ISSN : 22777105

Stephenson, A. P., Mazu, T.K., Miles, J. S., Freeman, M. D., Reams, R. R. and Flores-Rozas, H. 2013. "Defects in Base Excision Repair Sensitize Cells to Manganese in S. cerevisiae". BioMed. Res. Int. Article ID 295635. DOI : 10.1155/2013/295635

Subki, N. S., Hashim, R. and Muslim, N. Z. M. 2014. "Heavy Metals Analysis of Batik Industry Wastewater, Plant and Soil Samples : A Comparison Study of FAAS and $\mathrm{HACH}$ Colorimeter Analytical Capabilities" in A. Z. Aris et al., (Eds) From Sources to Solution pages 285-289. Springer Science and Business Media. Singapore

Thakur, B. R., Singh, R. K., Handa, A. K. and Rao, M. A. 1997. "Chemistry and uses of pectin A Review". Critical Rev. In Food Sci. and Nutri. 37 (1) : 47-73. DOI : 10.1080/10408399709527767

Toyokuni, S. 2009. "Role of Iron in Carcinogenesis : Cancer as a ferrotoxic disease". Cancer Sci. 100 (1) : 9-16. DOI : 10.1111/j.13497006.2008.01001.x

Yilmaz, E., Akyurt, I. and Gunal, G. 2004. "Use of Duckweed. Lemna minor, as A Protein Feedstuff in Practical Diets for Common Carp, Cyprinus carpio, Fry". Turk. J. Fish. Aquat. Sci. 4 : 105-109
Zhao, Z. Y., Liang, L., Fan, X. Q., Yu, Z. H., Hotchkiss, A. T., Wilk, B. J. and Eliaz, I. 2008. "The Role of Modified Citrus Pectin As An Effective Chelator of Lead in Children Hospitalized with Toxic Lead Levels". Altern. Ther. Health. Med. 14 (4) : 34-38 